Journal of the Scholarship of Teaching and Learning, Vol. 21, No. 1, April 2021, pp. 30-34. doi: 10.14434/josotl.v21i1.30356

\title{
The Impact of Continual Reflection Students as Partners: Becoming a/r/tographers
}

\author{
Diana Gregory \\ Kennesaw State University \\ dgregory@kennesaw.edu \\ Jonathan Fisher \\ Kennesaw State University \\ Hayley Leavitt \\ Kennesaw State University
}

\section{Introduction}

Research in visual arts, according to Winters (2015), is an unusual situation in that artists must offer details about how their artistic process represents a methodology, what its research methods are, and why this is an appropriate, reliable, and valid procedure. In this reflective article we are delineating a specific situation in which a/r/tography (Irwin, 2013) as a research methodology had a direct influence as a high-impact practice on an undergraduate's individual research project as well as collaborative work conducted with art and design co-co-principal investigators (coPI). We begin this reflective essay ever mindful of Sword's (2019) compelling question about writing research results with the identity-flattening pronoun we in situations where there is clearly a power imbalance between co-authors. We are Hayley, a Bachelor of Fine Arts (BFA) major who formulated undergraduate research projects as a co-investigator with Jonathan, a tenure track art and design faculty member coordinating foundation level courses who teaches ART 2990: Concepts, Creativity, and Studio Practice, and Diana, an art education professor whose research focus is creativity. Creativity, whether mundane or extraordinary, is an essential element in life (Richards, 2007). In art and design creative ability along with problem-solving ability are key expectations for students entering the field (National Association of Schools of Art and Design, 2019-2020). As art and design faculty, we recognize like Shreeve, Wareing, and Drew (2009) that from students' entrance into higher education and emergence into art and design fields as professionals, they are practitioners in their subject of study.

For Shulman (2005) signature pedagogies form habits of the mind, heart, and hand; they prefigure the cultures of professional work and provide socialization into the practices and values of a field (p. 59). Recognizing that creative education knowledge is unstable (Orr \& Shreeve, 2018), Jonathan and I received approval from our university's Institutional Review Board (IRB) to conduct a longitudinal study "Effective teaching of conceptual inventiveness and creativity in visual arts" to uncover what is it about creativity that students learn in our program. In this article, we chronicle working together from fall 2017 through spring of 2020 to discover what Rita Irwin (2013) delineated as "becoming a/r/tography" (p. 198). We delineate how undergraduate research as a high-impact practice affected the research experience of an art and design major, and how $\mathrm{a} / \mathrm{r} /$ tography as a research methodology influenced our research projects during this three-year period. 


\section{Becoming A/r/tography}

A/r/tography is concerned with self-study, being in community, and relational and ethical inquiry (Irwin \& Springgay, 2008, p. xix), while "living inquiry" refers to the ongoing practice of being an artist/researcher/teacher (p. xxix). Rita Irwin (2013) defined a/r/tography as "a research methodology, a creative practice, and a performative pedagogy that lives in the rhizomatic practices of the in-between" (p. 198). We found working as a/r/tographers "conceptualizing becoming (emphasis ours) within the multiplicities of our work" specifically in those "in-between spaces among the identities, practices, and processes of artists, researchers, and educators, and in the conditions of learning to learn" (p. 202) to be a synchronous research method that enhanced and deepened our scholarship of teaching and learning (SoTL) projects. As a methodology, it had a direct impact on Hayley's undergraduate research project(s) as well as the collaborative work she conducted with us as co-PIs. Jonathan and I began our SoTL journey focusing on signature pedagogies (Shulman, 2005) to understand why art and design students develop as they do, what forms of development and approaches enabled them to think and act as professional artists and designers. However, in art and design, Orr and Shreeve (2018) note the "sticky" creative curriculum leaves us with a tension between creativity and clarity, with a discomfort of not knowing all the answers, but with a need to support student learning (p. 157). The art and design curriculum is "sticky" since it is "messy and uncertain; values stick to it in ways that are difficult to see; it has an elasticity, being both sticky and stretchy; it is embodied and enacted - it sticks to the person; and it is troublesome and challenging" (p. 7).

As a/r/tographers, we pursued presenting our "living inquiry" moments not as end results, but as understandings of experiences along the way (Irwin \& Springgay, 2008, p. xxix). To navigate our So'TL landscape (O'Brien, 2008) we asked: what is it that students learn about creativity; what activities enable the learning/growth/development to occur; and how to support students. Early case study results, presented at the 2017 International Society for the Scholarship of Teaching and Learning conference, included the impact of adding ART 2990: Concepts, Creativity, and Studio Practice to the foundation core curriculum; vertical and horizontal alignment (Angelo, 2012); and, a modified Creativity VALUE Rubric (AAC\&U, 2009) in the assessment process (Gregory, Fisher, Brasco, Robson, \& Sipp, 2017). While these results documented faculty (micro) and departmental (meso) steps toward meaningful change, student engagement, and most importantly, student voice was lacking (Felten, Bagg, Bumbry, Hill, Hornsby, Pratt, Weller, 2013) in our research focus. Through a/r/tography, we sought out critical friends to provoke us to think critically, and to inspire us to work creatively (Irwin, 2008). Although our presentation provided a rhizome - the groundwork/wire framework - for our learning to unfold and grow, the challenge was to perceive freshly, to notice the in-between spaces - the rhizomatic relations, looking for critical concepts rather than for isolated facts (Irwin \& Springgray, 2008).

To include student voice in our research process, Jonathan and I held focus groups (Nagle \& Casey, 2018) to document students' views on creativity in spring 2017. The focus group script was based on a creativity model developed by faculty in a School of Art and Design Faculty Learning Community from 2009-2011. The model included Sawyer's (2012) individualist and sociocultural approach to creativity and Runco's (2009) person, place, process, product (4P) perspective. At the end of our first session, we invited anyone interested in this research to contact us, and Hayley did. She asked if she could work with us on the focus group as a coPI. She completed CITI training, then began leading the next focus group sessions. Additionally, she met with Jonathan who mentored her as she developed an individually IRB approved study, "The Effects of Freedom on Creativity, Productivity, and Motivation" asking in part: what does freedom mean in studio settings and is there a difference between creative freedom in foundation versus advanced level courses? 
Douglass and Zhao (2013) note that independent student research projects are a more reliable mechanism for student learning rather than just assisting faculty with their research projects.

Undergraduate research as a high-impact practice holds an important place at our institution (Kuh, 2008). Hayley's inquiry was based on the role of being an undergraduate researcher within the BFA program as she moved from foundation to upper division courses, while examining the role of creativity and freedom within the curriculum. With Hayley's preliminary study designed and in progress, she continued to meet and work with us on the focus groups which the results were presented at the 2018 ISSoTL Conference in Bergen, Norway (Fisher, J., Gregory, D. \& Leavitt, H., 2018). At the conference, Hayley also presented a draft of her own study. With the valuable information she received following her conference presentation, she redesigned her study and began interviewing faculty as she matriculated through the program. In 2019, she submitted her pilot study results to the National Council on Undergraduate Research (NCUR) conference and was accepted. a We posit that research is assessed during the $\mathrm{a} / \mathrm{r} /$ tography process. Like Irwin and Springgay (2008), we believe that "our actions, encounters, and thoughts - our living inquiry - as substance that can be arranged in discrete moments, counted, and subjected to normative evaluations, we need to understand living inquiry as responsibility" (p. xxxii). Working as a/r/tographers allowed us to reflectively and collaboratively develop research questions, collect data, and present "Influence Mapping The Four Ps of Creativity: Student Engagement, a/r/tography and SoTL", (Fisher, Gregory, \& Leavitt, 2019) and "Students as SoTL Partners: How Reflective Practice Impacts Student Learning in Art and Design" (Fisher, Gregory, \& Leavitt, 2019) at SoTL Commons and the Kennesaw State University Research on Teaching and Learning Summit conferences, respectively.

Irwin and Springgay describe a/r/tography as a methodology of embodiment, of continuous engagement with the world; one that interrogates yet celebrates meaning; it is a living practice; a life creating experience examining our personal, political and/or professional lives. As a qualitative inquiry method, the data can include interviews, journal writings of teachers or students, inquiry such as painting, photography, composing music/poems, narratives, or other forms of artistic inquiry. It is important to note the reflective/reflexive stance to analysis - it is ongoing and "may include aspects from traditional ethnographic forms of inquiry such as constantly comparing themes that emerge from the data" (p. xxix). A/r/tography allowed us to pay attention to the ongoing inquiry through an evolution of research questions and understandings. Rather than pursue a thesis with a/r/tography we pursued exegesis - a critical explanation of the meaning within a work . Our living inquiry provided opportunities for us to have conversations and relationships while paying attention to what we could see and know, and yet, to also pay attention to what is not seen and not known.

\section{Conclusion}

Hayley's final study was accepted to NCUR 2020. Over the course of three years, Hayley sought out and took advantage of mentorship and reflective practice paving a path to be an independent researcher as well as an equal partner with faculty members. In her own words:

I see this experience as impacting my future role as an educator. I've asked questions that I hope to one day turn on myself in introspection and self-reflection. As other students learned about my experience, they too began to see that research within studio art is possible. This experience has opened the door for other students to become curious about research and be motivated to find the answers to their own questions (personal communication, 2020). 
Her last sentence was particularly important to us. Mentoring other studio-based students for undergraduate research is our priority. In 2019 and 2020, two additional studio-art BFA candidates had projects accepted at NCUR. Through a/r/tography, we want to encourage and foster a culture of research within the school of art and design, particularly for studio-based faculty and students that may feel alienated from traditional quantitative research methodologies. In the arts, learning outcomes often exist in the form of storytelling, expressive personal narratives, and acknowledging divergent perspectives. Creativity can be inquiry. Like deFreitas (2007) we believe the primacy of the creative work in the research process validates the insight and learning artists and designers gain when they examine the creative process and the materiality of their work. Further, we also concur with Orr \& Shreeve (2018) that learning outcomes (LOs) should offer signposts rather than a destination, and by embracing a degree of ambiguity or stickiness, LOs can support the development of creativity while allowing for diversity of output and differentiation. Leggo (2008) notes pedagogy is all about transformation, but that many of us do not live without the privilege of telling our stories or the privilege to be heard. Students as partners in art and design research may be an emerging field of inquiry. However, we believe a/r/tography aims to encourage artists/researcher/teachers in creative disciplines by allowing their stories to be told.

\section{References}

Angelo, T. (2012). Designing subjects for learning: Practical, research-based principles and guidelines. In Hunt, L. \& Chalmers, D. (Eds.), University Teaching in Focus: A Learning-centered Approach. London: Routledge, 93-111.

Association of American Colleges and Universities (AAC\&U). (2009). Inquiry and analysis $V A L U E$ rubric. Retrieved from https://www.aacu.org/value/rubrics/inquiry-analysis

de Freitas, N. (2007). Activating a research context in art and design practice. International Journal for the Scholarship of Teaching and Learning (1)2, Article 14.

Available at: https://doi.org/10.20429/ijsotl.2007.010214

Douglass, J. A., Zhao, C.-M., \& University of California, B. C. for S. in H. E. (2013). Undergraduate research engagement at major US research universities. Research \& Occasional Paper Series: CSHE.14.13. In Center for Studies in Higher Education. Center for Studies in Higher Education.

Felten, P., Bagg, J., Bumbry, M., Hill, J., Hornsby, K., Pratt, M., Weller, S. (2013). A call for expanding inclusive student engagement in SoTL, Teaching \& Learning Inquiry, 1(2), 63-74.

Fisher, J., Gregory, D. \& Leavitt, H. (2018, October). Constructing a learner's culture: Merging student voice, studio pedagogy, creativity, and SoTL. Panel presented at International Society for the Scholarship of Teaching and Learning Conference, Bergen, Norway.

Fisher, J., Gregory, D. \& Leavitt, H. (2019, January). Influence mapping the 4P's of creativity: Studio engagement, a/r/tography, and SoTL. Panel presented at SoTL Commons Conference, Savannah, GA.

Fisher, J., Gregory, D. \& Leavitt, H. (2019, October). Students as SoTL partners: How reflective practice impacts student learning in art and design. Panel presentation at the Research on Teaching and Learning Summit, Kennesaw, GA.

Gregory, D., Fisher, J., Brasco, C., Robson, D., \& Sipp, G. (2017, October). SoTL contours in visual arts: Delineating an emerging future. Panel presented at International Society of the Scholarship of Teaching and Learning Conference, Calgary, Canada.

Irwin, R. (2008). Communities of a/r/tographic practice. In Stephanie Springgay, Rita Irwin, Carl Leggo, \& Peter Gouzouasis (Eds.) Being with a/r/tography, Rotterdam: Sense. 
Irwin, R. (2013). Becoming A/r/tography. Studies in Art Education: A Journal of issues and Research, 54(3), 198-215.

Irwin, R., \& Springgay, S. (2008) A/r/tography as practice-based research. In Stephanie Springgay, Rita Irwin, Carl Leggo, \& Peter Gouzouasis (Eds.) Being with A/r/tography, Rotterdam: Sense.

Kuh, G. D. (2008). High-impact educational practices: What they are, who has access to them, and why they matter. Washington, DC: Association of American Colleges and Universities.

Leggo, C. (2008). Autobiography: Researching our lives and living our research, in Stephanie Springgay, Rita Irwin, Carl Leggo, and Peter Gouzouasis (Eds.), Being with A/r/tography. Rotterdam: Sense.

Nagle, B. \& Willimas, N. Methodology Brief: Introduction to Focus Groups. Retrieved online on July 15, 2018: http://www.mmgconnect.com/projects/userfiles/File/FocusGroupBrief.pdf

National Association of Schools of Art and Design Handbook (2019-2020). Retrieved online on March 15, 2020: https://nasad.arts-accredit.org/wp content/uploads/sites/3/2019/12/NASAD-Handbook-2019-20.pdf

O’Brien, M. (2008). "Navigating the SoTL landscape: A compass, map and some tools for getting started." International Journal for the Scholarship of Teaching and Learning, 2(2), Article 15. Available at: https://doi.org/10.20429/ijsotl.2008.020215

Orr, S., \& Shreeve, A. (2018). Ambiguity and uncertainty in creative education. In Art and Design Pedagogy in Higher Education: Knowledge, values and ambiguity in the creative curriculum, Orr, S. \& Shreeve, A. (Eds.). New York: Routledge.

Richards, R. (2007). Everyday creativity: And new views of human nature, psychological, social, and spiritual perspectives. Washington, D.C.: APA. Online: www.apa/org/books/

Sawyer, R. K. (2012). Explaining creativity: The science of human innovation ( $\left.2^{\text {nd }} \mathrm{Ed}\right)$. Oxford and New York: Oxford.

Shreeve, A, Warening, S. \& Drew, L. (2009). Key aspects of teaching and learning in visual arts. In H. Fry, S. Ketteridge \& S. Marshall (Eds.), A handbook for teaching and learning in higher education: Enhancing academic practice. New York and London: Routledge.

Shulman, L. (2005). Signature pedagogies in the professions. Daedlus, 134:3, 52-59. Available at: http://www.jstor.org/stable/20027998

Sword, H. (2019). The first person. Teaching and Learning Inquiry, 7(1). Available at: http://dx.doi.org/10.20343/teachlearninqu.7.1.12

Winters, T. (November-December, 2015). Facilitating early research experience in art and design using a research-oriented approach to teaching and learning. Paper presented at the Annual Meeting of the Australian Association for Research in Education, Freemantle, Western Australia (ED593810). 